\title{
Occurrence of antibodies to Toxoplasma gondii in water buffaloes and meat cattle in Rio Grande do Sul State, southern Brazil
}

\author{
Laura M. J. de F. Santos' ${ }^{1}$ Maria Cecília F. Damé2, Beatris G. Cademartori', \\ Nilton A. da Cunha Filho ${ }^{3}$, Nara Amélia da R. Farias ${ }^{1}$ and Jerônimo L. Ruas ${ }^{4 *}$ \\ ${ }^{1}$ Microbiology and Parasitology Department, Institute of Biology, Federal University of Pelotas, Brazil; \\ ${ }^{2}$ Brazilian Agricultural Research Corporation- Embrapa Temperate Agriculture-Pelotas/RS; \\ ${ }^{3}$ Postgraduate Program in Veterinary, Federal University of Pelotas, Brazil; \\ ${ }^{4}$ Regional Veterinary Diagnosis Laboratory, Faculty of Veterinary Medicine, Federal University of Pelotas, Brazil
}

\begin{abstract}
Serum samples from 169 water buffaloes and 121 beef cattle were analyzed for antibodies to T. gondii by an indirect fluorescent antibody test (IFAT). Positive results were obtained in $27.2 \%$ of water buffaloes and $17.4 \%$ of cattle. Statistical analysis indicated significant differences between the prevalence in cattle and buffalo $(\mathrm{p} \leq 0.05)$. The highest titres found in positive animals were 1:256 (buffaloes) and 1:64 (cattle). In both bovine species, toxoplasmosis frequency in young animals (less than 2 years old) was lower compared to older individuals, although the differences seen in cattle were not statistically significant.
\end{abstract}

\section{Keywords}

Bubalus bubalis, water buffaloes, toxoplasmosis, cattle, felids

\section{Introduction}

Toxoplasmosis is a disease caused by Toxoplasma gondii, an obligatory intracellular, protozoan parasite which is a member of the phylum Apicomplexa (Rorman et al. 2006; Dubey 2008). Cats, including both domestic and wild felids, are the definitive hosts of this parasite (Dubey 2008; Jones and Dubey 2010). T. gondii is prevalent in most areas of the world and is of veterinary and medical importance, because it may cause abortion or congenital disease in its intermediate hosts, including humans. In Brazil, previous studies have shown that T. gondii infections in animals and man are relatively frequent. The infection in cattle does not usually cause clinical symptoms as these hosts show high natural resistance to the parasite (Dubey and Thulliez 1994). However, little is known about the prevalence of $T$. gondii antibodies in water buffaloes (Bubalus bubalis), but the indications are that prevalence is generally lower than in cattle (Dubey et al. 1998; Huong et al. 1998), albeit one study in Brazil showed the opposite tendency. Water buffaloes and cattle are a main source of animal proteins and products such as bones, skins and goods made from their hides are of great importance for man (Kakar and Kakarsulemankhel, 2008). Since there is a trend to increase the number of water buffaloes farmed in Brazil, we considered it necessary to investigate the importance of $T$. gondii in bovines.

\section{Materials and Methods}

\section{Blood samples}

A total of 290 blood samples (169 water buffaloes and 121 cattle) were obtained from a single farm. The samples were collected during a three month period (May - July 2011). The group of water buffaloes consisted of Murrah females of different ages (1-18 years old), whereas the cattle were Charolais of both sexes and of different ages (1-12 years old). None of these animals had a history of recent abortions or showed any disease signs. The farm under study was located in the 
Table I. Comparison of positivity of anti-T. gondii antibodies obtained (IFAT) according to the age in water buffaloes and beef cattle in southern, Brazil

\begin{tabular}{lccccc}
\hline Species & \multicolumn{5}{c}{ Age in years } \\
\cline { 2 - 6 } & $1-2$ & $2,1-4$ & $4,1-6$ & $6,1-8$ & $>8$ \\
\hline Cattle & $9(14,8 \%)^{\mathrm{a}}$ & $0(0 \%)^{\mathrm{a}}$ & $8(22,2 \%)^{\mathrm{a}}$ & $4(20 \%)^{\mathrm{a}}$ & $0(0 \%)^{\mathrm{a}}$ \\
Buffalo & $18(19,8 \%)^{\mathrm{a}}$ & $09(47,4 \%)^{\mathrm{b}}$ & $08(40 \%)^{\mathrm{a}, \mathrm{b}}$ & $04(44,4 \%)^{\mathrm{a}, \mathrm{b}}$ & $07(23,3 \%)^{\mathrm{a}, \mathrm{b}}$ \\
\hline
\end{tabular}

*Value followed by different letters in the same line differ statistically. Regarding age, the prevalence was $19.8 \%$ for $1-2$ age and significantly higher for adults: $47,4 \%\left(\mathrm{x}^{2}=9.66, \mathrm{P}<0.05\right)$.

State of Rio Grande do Sul in southern Brazil $\left(31^{\circ} 42^{\prime} \mathrm{S}\right.$, $\left.52^{\circ} 24^{\prime} \mathrm{W}\right)$. Blood samples (5-10 $\mathrm{ml}$ from cephalic veins) were collected by qualified health professionals from the University Federal of Pelotas (the present study was approved by the University Federal of Pelotas Animal Ethics Committee with number 2744). Blood was recovered in tubes without anticoagulant and serum was separated by centrifugation at $1800 \mathrm{x}$ $\mathrm{g}$ for $10 \mathrm{~min}$ at room temperature. Samples were subsequently stored at $-20^{\circ} \mathrm{C}$ until use.

\section{Serological tests}

The sera from experimental animals were analyzed for anti- $T$. gondii antibodies by employing a commercial indirect fluorescent antibody test (Camargo 1974). The sera were screened at dilutions of 1:64 to 1:256 and an IFAT titer of 1:64 was regarded as a cut-off level for $T$. gondii antibodies. Sera from non-infected and experimentally infected bovine calves were included as negative and positive controls in both tests.

\section{Statistical analyses}

Seroprevalence of anti-T. gondii antibodies was calculated separately for cattle and buffaloes. For the statistical analysis of the possible effects of the attributes of species range on the occurrence of anti- $T$. gondii antibodies the chi-squared test was used, at a significance level of $95 \%(\mathrm{p}<0,05)$ using $2 \mathrm{x}$ 2 contingence tables with one degree of freedom, and different age groups of buffalo and cattle using $2 \times 5$ contingence tables with four degree of freedom. Statistical analyses were performed by using EpiInfo, version 6.04.

\section{Results and Discussion}

Analysis of 169 water buffaloes and 121 meat cattle serum samples revealed relatively high prevalence of $T$. gondii infection $(27.2 \%$ and $17.4 \%$, respectively). With regard to the bovine species, significant differences in toxoplasmosis level were readily seen $\left(x^{2}=3.86, p<0.05\right)$. The highest titer in cattle was $1: 64$ and in buffaloes was $1: 256$. Age group had a significant effect on seroprevalence in the water buffaloes $\left(\mathrm{x}^{2}=\right.$ $9.66, \mathrm{p} \leq 0.05$ ) (Table I). However, no significant effect on seroprevalence existed between age group in cattle (Table I).
Previous results in Brazil and other countries have indicated lower prevalence of $T$. gondii in bovines (no more than 4\%, as reported by Huong et al. 1998; Gondim et al. 1999; Fujii et al. 2001 and Silva et al. 2010, which is in contrast to the results reported here. The reason for such a discrepancy may be due to the fact that changes in feline populations are occurring in the area under study. First, relocation of endangered felines is underway in the state of Rio Grande do Sul, as a result of the activities endorsed by the Wildlife Rehabilitation Centre Program. These activities may have increased the dissemination of Toxoplasma oocysts in the area, as observed in other geographic locations (Silva et al. 2007; Dubey 2009; Jones and Dubey 2010). Second, a rural settlement location near to the grazing area has been closed since 2008, which has led to the abandonment of domestic cats. These stray animals now feed on birds or small wild mammals, including rodents in that area, and this is likely to increase their chances of contracting toxoplasmosis (Dubey and Beattie 1988; Albuquerque et al. 2011). It is evident that bovines, such as herbivorous mammals, may have been infected only by widespread oocyst contamination occurring in their habitat, especially on the pastures that they graze (Frenkel 1970; Miller et al. 1972; Dubey and Beattie 1988; Dubey and Jones 2008).

The finding that older water buffaloes showed a tendency to higher levels of toxoplasmosis is not surprising since this fact has been observed previously both in humans (Speare 1985) and animals (Persad 2011). The fact that the same effect was not observed in cattle may have been due to the smaller sample size for this group. Alternatively, age may not be an important factor influencing susceptibility to toxoplasmosis in that species.

The present results are very interesting, especially our finding of a moderate prevalence of toxoplasmosis in bovines. Products derived from these animals may be infective to man. Preliminary studies conducted by us in the sampled farm indicate that toxoplasmosis in humans has a low prevalence, although the group studied was too small to draw any definitive conclusions on this matter. From 1975 to 2000 , the water buffalo population in the Brazilian Amazon increased at nearly $13 \%$ per year, making it one of the fastest growing herds in the world (Sheikh et al. 2006). This fact underlines the need for a better understanding of zoonosis such as toxoplasmosis that may be transferred from domestic animals to man. 


\section{References}

Albuquerque G.R., Munhoz A.D., Teixeira M., Flausino W., Medeiros S.M., Lopes C.W.G. 2011. Risk factors associated with Toxoplasma gondii infection in dairy cattle, State of Rio de Janeiro. Pesquisa Veterinária Brasileira, 31, 287-290.

Camargo M.E. 1974. Introdução às técnicas de imunofluorescência. Revista Brasileira de Patologia Clínica, 10, 87-107.

Dubey J.P., Beattie C.P. 1988. Toxoplasmosis of Animals and Man. CRC: Press, Boca Raton. Dubey J.P., Thulliez P. 1994. Persistence of tissue cysts in edible tissues of cattle fed Toxoplasma gondii oocysts. American Journal of Veterinary Research, 54, 270-273.

Dubey J.P. 1998. Toxoplasma gondii oocyst survival under defined temperatures. Journal of Parasitology, 84, 862-865.

Dubey J.P. 2004. Toxoplasmosis - a waterborne zoonosis. Veterinary Parasitology, 126, 57-72. DOI: /10.1016/j.vetpar.2004.09. 005.

Dubey J.P. 2008. The history of Toxoplasma gondii - the first 100 years. Journal of Eukaryotic Microbiology, 5, 467-475. DOI: /10.1111/j.1550-7408.2008.00345.x.

Dubey J.P., Jones J.L. 2008. Toxoplasma gondii infection in humans and animals in the United States. International Journal for Parasitology, 38, 1257-1278.

Dubey J.P. 2010.Toxoplasmosis of Animals and Humans CRC: Press, Boca Raton.

Centers for Disease Control and Prevention. Epi Info [online]. 2005 [cited 2008 Feb 10]. Available from: http://www.cdc.gov/epiinfo/ei2005.htm.

Dubey J.P. 2009. Toxoplasmosis in sheep - The last 20 years. Veterinary Parasitology, 163, 1-14. DOI: 10.1016/j.vetpar.2009. 02.026 .

Frenkel J.K. 1970. Pursuing Toxoplasma. Journal of Infection Disease, 122, 553-550.

Fujii T.U., Kasai N., Nishi S.M., Dubey J.P., Gennari S.M. 2001. Seroprevalence of Neospora caninum in female water buffaloes (Bubalus bubalis) from the southeastern region of Brazil. Veterinary Parasitology, 99, 331-334. DOI: 10.1016/ S0304-4017(01)00474-5.

Gondim L.F.J., Barbosa Jr. H.V., Ribeiro-Filho C.H.A., Saeki H. 1999. Serological survey of antibodies to Toxoplasma gondii in goats, sheep, cattle and water buffaloes in Bahia State, Brazil. Veterinary Parasitology, 82, 273-276. DOI: 10.4061/ 2011/705358.

Huong L.T.T., Ljungström B.L., Uggla A., Björkman C. 1998. Prevalence of antibodies to Neospora caninum and Toxoplasma gondii in cattle and water buffaloes in southern Vietnam. Veterinary Parasitology, 75, 53-57. DOI: 10.4061/2011/705358.

Jones J.L., Dubey J.P. 2010. Waterborne toxoplasmosis - Recent developments. Experimental Parasitology, 124, 10-25. DOI: 10.1016/j.exppara.2009.03.013

Kakar M.N., Kakarsulemankhel J.K. 2008. Prevalence of endo (trematodes) and ecto-parasites in cows and buffaloes of Quetta, Pakistan. Pakistan Veterinary Journal, 28, 34-36.

Miller N.L., Frenkel J.K., Dubey J.P. 1972. Oral infections with Toxoplasma cysts and oocysts in felines, other mammals and birds. Journal of Parasitology, 58, 928-937.

Persad A., Charles R., Adesiyun A.A. 2011. Frequency of Toxoplasmosis in Water Buffalo (Bubalus bubalis) in Trinidad. Veterinary Medicine International, 1, 1-4. DOI: 10.4061/2011/ 705358.

Rorman E., Zamir C.S., Rilkis I., Ben-David H. 2006. Congenital toxoplasmosis - prenatal aspects of Toxoplasma gondii infection. Reproductive Toxicology, 21, 458-472. DOI: 10.1016/ j.reprotox.2005.10.006.

Sheikh P.A., Frank D. Merry F.D., McGrath D.G. 2006. Water buffalo and cattle ranching in the Lower Amazon Basin: Comparisons and conflicts. Agricultural Systems, 87, 313-330. DOI: 10.1016/j.agsy.2005.02.003.

Silva J.C., Marvulo M.F.V., Dias R., Ferreira F., Amaku M., Adania C.H., Ferreira Neto J. S. 2007. Risk factors associated with sero-positivity to Toxoplasma gondii in captive neotropical felids from Brazil. Preventive Veterinary Medicine, 78, 286295. DOI: 10.1016/j.prevetmed.2006.10.013.

Silva S.P., Mota R.A., Faria E.B., Fernandes E.F.T.S, Neto O.L.S., Albuquerque P.P.F., Dias H.L.T. 2010. Anticorpos IgG antiNeospora caninum e Toxoplasma gondii em búfalas (Bubalus bubalis) criadas no estado do Pará. Brazilian Journal of Veterinary Research, 30, 443-446.

Speare R. 1985. The veterinary aspects of man as an intermediate host for Toxoplasma gondii. Australian Veterinary Practice, $15,11-18$. 